\title{
Relationships between Innovations and Productivity in the Services in the Slovak Economy
}

\author{
Viera Kubičková ${ }^{*}$, Dana Benešová ${ }^{1}$, Daniela Breveníková ${ }^{2}$
}

\begin{abstract}
A key factor of increasing performances of service enterprises and in effect, that of the entire economy is the introduction of innovations. However, it is the final effect of the process that is important, rather than the type of innovation introduced by an enterprise. The aim of the paper is to verify the validity of the relationship between the innovation activity of service enterprises in Slovak Republic and their economic performance. Results of analysis have not demonstrated unanimously a positive relationship between innovations and the productivity of business service. The reason for that is in the so far low innovation performance of services as well as in the low time-related homogeneity of the implementation and the effect of innovations.
\end{abstract}

Keywords: innovations; performance indicators; productivity; service enterprises; enterprises with technology innovation

Submitted: $\quad$ March 23 $3^{\text {rd }} 2016 /$ Approved: June $7^{\text {th }} 2016$

\section{Introduction}

In recent years, the Slovak economy has passed significant structural changes. Despite the key role of automobile, engineering and the electrical engineering industries, the position of services has been strengthening. At the same time, we can mention that the economic power of industry supports the development of the service sector in particular through intermediary consumption. The tertiary sector represents the largest sector of the national economy, as evidenced by its share on the national economy. According to the Slovak Statistics (2015) services in Slovakia employ as many as $65.4 \%$ employees. The share of the service sector on the creation of value added is at present $62.73 \%$. It is therefore justifiable to deal with the issues of the application of innovations in the service sector of the SR as the driving factor of its economic development.

Innovation performance in SR's services may be evaluated by means of selected European Service Innovation Scoreboard (European Commission, 2015) indicators. During the period monitored (2012), the value of almost all the indicators achieved in the SR was below the European Union's average. Merely the share of the turnover from launching new innovations onto the market was higher than in the EU. Slovakia is considerably lagging behind the European Union in the innovation performance of the service sector. A more detailed analysis of applying innovations in Slovakia's service sector is carried out by the Slovak Statistics in the report on "Innovation activity of enterprises in the Slovak Republic during 2010 - 2012" (the Slovak Statistics, 2014). The document informs that the share of service enterprises with innovation activities of the total number of service enterprises in the years 2010 - 2012 was $35.8 \%$. As much as $64.2 \%$ of enterprises in the years 2010-2012 did not implement any innovation activities, although the innovation performance of service enterprises was higher than that of enterprises in industry. The highest share of enterprises with technology innovation in industry and services was scored by successfully innovating enterprises. Only $2.8 \%$ of them were enterprises with incomplete or suspended innovation activities. $42.1 \%$ of enterprises in industry and services conducted non-technology innovations (marketing, organizational) innovations. The highest share of innovation activities was recorded in large enterprises (250 and more employees). However, the mentioned materials fail to provide the analysis into economic consequences of innovation activities. Despite that, they have become the starting point materials for the scientific intent of the present paper.

Based on numerous theoretical sources and empirical experience with the real-life economic practice, we can identify the assumption of a positive relationship between innovations and economic performance. It is logical that in the effort for the sustainable development, expenditures on innovations are confronted with accompanying effects, while at the same time, these pragmatic procedures are required on the enterprise level as well as on that of the country's economy. The economic benefit of innovations is a crucial stimulus for innovation investment.

When considering the methodology applied in the European Commission Report on the results of innovation performance of countries in the year 2014 (European Commision, 2014), it can be said that the countries recording the highest expenditures on innovation activities (Germany, Sweden, Denmark, Finland) are at the same time leaders in the area of innovations in Europe. On the ladder of global of competitiveness, they occupy the first twelve positions (World Economic Forum, 2016). Innovations are clearly a factor that influences the country's economic growth. As a rule, innovations arise in enterprises, and thus influence their competitiveness and growth. Competitive enterprises are beneficial for the GDP growth and contribute to the change in its economic structure (Sedláček, 2014). Effective

(1) University of Economics in Bratislava, Faculty of Commerce, Department of Services and Tourism, Dolnozemská cesta 1, Bratislava, Slovak Republic. (2) University of Economics in Bratislava, Faculty of Applied Languages, Department of Lingistics and Translatology, Dolnozemská cesta 1, Bratislava, Slovak Republic.

${ }^{*}$ Corresponding author: viera.kubickova@euba.sk 
production is therefore an aspect of competitiveness. Exploring relationships between investments in research and innovations, in terms of scope of innovation activity and economic effectiveness is thus a relevant research intent.

The influence of innovations on performance of American enterprises of commercial business services were explored by Mansury and Love (2008), who investigated into the differences between the level of innovations in service enterprises, to what extent the service enterprises utilise external innovations and the influence of the introduction of external innovation on the enterprise performances. Results indicate that the introduction of innovations in service enterprises have permanently recorded a favourable influence on growth, rather than on the production of services. Brawn and Mawson (2013) identify innovations as growth stimulus in enterprises. The academic and professional public are convinced that the innovation of services substantially affects the enterprise performance and are a key factor of adaptation, sustainability and growth (Rhee, Park and Lee, 2010).

Specific characteristics of services however, bring many queries regarding the methodology and application into the problems of the relationship between innovations and their economic effects. They focus in particular on determining the unit of performance in services; the influence of the client performance on the process of service production; mutually linked efficiency of individual types of service innovation; broad-range ICT effects in service innovation activities; as well as on the relationship between productivity and quality.

In the present paper, the productivity of labour expressed in terms of volume of turnover on an employee and the gross value added per an employee are used as an indicator of economic performance. The aim of the article is to identify the relationship between the innovation activity of enterprises and the productivity of labour in services in the Slovak economy.

\section{Literature Review}

\section{Productivity in Services}

Until recently, productivity of services was conceptionally underdeveloped (Corsten, 2001). Most of the definitions are derived from the classic concept of productivity (Sink, 1985); however, as a result of impalpable and intangible nature of services, a simple transfer of the traditional productivity concept from industry producing tangible goods into services, is inaccurate and misleading (Corsten, 2001, Baumgartner, Bienzeisler, 2006, Lasshof, 2006, Grönroos, Ojasalo, 2004, Johnston, Jones, 2004). The intangible nature of services results from the impalpability of the output of service production, as well as the heterogeneity of services as another service property complicates the creation of a generally valid conception of productivity of services. Services are highly diversified, broad-range, covering services starting from public services through services for enterprises, which are predominantly knowledge-intensive, up to personal services. These have various properties, consequently it is difficult to determine significant productivity factors and their specificities (Lasshof, 2006, Ojasalo, 1999, Baumgartner, Bienzeisler, 2006).
Apart from that, the customer integration and their involvement in the process of value creation is the main element in the production of services (Lasshof, 2006, Michalová and Krošláková, 2014). It means that the customer, who has to be in some way integrated and involved in the measuring of service productivity, is inevitably a key factor for service providers. This is in contrast to the classical concept of productivity, when the customer is usually not an inseparably part of the value creation, and commercial processes are often closed systems (Grönroos and Ojasalo, 2004). It means that the production in the course of value creation, i.e. in during production and selling, cannot and must not be influenced by the customer.

Existing conceptual approaches to the productivity of services consider several factors affecting its measuring (Lasshof, 2006, Grönroos and Ojasalo, 2004, Johnston, Jones, 2004, Corsten, 1994, Gummesson, 1998). However, nowadays there is no unified definition of the productivity of services, nor a generally applicable method of its measuring (Johnston, Jones 2004). The problem involved in defining the method of measuring productivity lies in the specific nature of services, as well as in the difficulty of quantifying the customer participation in the service production process (Nachum, 1999, Vuorinen, Järvinen, Lehtinen, 1998, Grönroos and Ojasalo 2004, Jääskeläinen, 2010).

The method of measuring productivity is currently worked out and utilised for the production of the manufacturing industry (Den Hartigh and Zegveld, 2011, Brown and Chávez, 2014), where productivity is defined as the ratio of production outputs and inputs. In contrast to it, the measuring of productivity of services has not been precisely and consistently defined to date. Identifying service productivity is not however unsubstantiated, as the service production (in contrast to manufacturing) to a great extent requires the participation of people, technologies, internal and external stakeholders mutually linked in the value creation and sharing information. As a result of this, there is no universal definition of the productivity of services (Hilke, 1989, Maleri and Frietzsche, 2008).

The model of productivity of services according to Grönroos and Ojasalo (2004) is one the main existing conceptions in scientific literature (Balciet al., 2011), enhancing the classical concept of the productivity of services. It is based on the process approach and defines the productivity of services as a complex of various funkctional components. From the aspect of the service provider, productivity of services is determined by three main factors: internal, external and capacity utilisation.

The internal efficiency is identified by the internal structure of the service production, including the service provider's and customers' inputs; the external efficiency depends on the quality of outputs, mainly from the service quality as evaluated by customers and the output quantity; an efficient capacity utilisation means an optimum utilisation of enterprise capacities in relation to the production quantity. The utilisation of capacity is optimal, if the demand and the supply are in equilibrium. What is important is the service provider's ability to maintain cost-effectiveness (internal efficiency) and the coordination of sources with customer expectations regarding the quality (external efficiency) together with the utilisation of an enterprise's capacity (capacity efficiency) (Balci et al. 2011). 
This way the traditional model of service productivity was enhanced by the customer (Vuorinen; Järvinen; Lehtinen, 1998). If the quality and customer satisfaction are included into the concept of productivity, service enterprises can anticipate a higher customer loyalty, higher profit and a higher customer participation (Grönroos, Ojasalo, 2004). However, if we take into consideration the customer participation in the process of service production, their role does not lie only in the quality assessment, since in some services the customers are directly involved in the process of service production, and thus their role is equally important as as that of the service provider (Grönroos; Ojasalo, 2004).

"In view of properties of services and the process of service production, the managing of external efficiency of the performance (identification of the quality of services), has to be an inseparable part of the concept of productivity of services" (Grönroos and Ojasalo, 2004). A purely quantitative approach fails to capture all the specific characteristics of service production and does not express the effectiveness of a service. It means that it is necessary to focus on the quality of outputs. Productivity is evaluated only or mainly from the aspect of a service provider. However, the main role is played by the customer satisfaction. The better is the assessment of the service quality (How is it viewed by the customer? - Is the customer satisfied or not?), for the production of which a certain amount of inputs was expended, the better is the external efficiency, which results in the improvement of production of services (Grönroos and Ojasalo, 2004).

As far as the relationship between the productivity of services and the quality of services is concerned, some researches claim that productivity and quality are inseparable parts of the whole (Grönroosand Ojasalo, 2004, Gummesson, 1998), while others argument that productivity is independent of quality and may be perceived per se as an expression of the qualitative benefit, which is distinct from the quantitative result (Lasshof, 2006, Nachum, 1999). However, all scholars agree that it is the customer who determines the quality of service (Lasshof, 2006; Grönroos and Ojasalo, 2004).

According to Lasshof (2006), productivity is influenced to a crucial extent by the customer, who assesses the quality of service (one aspect of quality). This parameter measures and evaluates production effectiveness. Since the customer is a crucial factor of the service provider's success, it is necessary to exert parallel pressure on the production effectiveness and customer satisfaction, (Lasshof, 2006). The increase in both magnitudes at the same time, leads to general advantage. Lasshof (2006) also suggests that the reflections on productivity also ensue that the effectiveness of production and productivity expressed in quantitative terms may be evaluated separately from one another (Lasshof, 2006).

There are therefore two different views of the productivity of services. In one approach the productivity of services is viewed as part of effectiveness, even though it emphasises the importance of customer satisfaction.

As a result of this, productivity is expressed in terms of the quantitative performance indicator and is separated from the component of qualitative result. On the other hand, the other approach views productivity and the complex integrating efficiency and performance. In accordance with this view, productivity cannot be separated from quality.

It is also assumed that there remains a large number of various factors in existence, which influence the productivity of services. However, only few of these factors for determining productivity have been examined in greater detail to date. For these reasons, we apply the quantitative approach to defining the productivity expressed as the share of turnover per an employee.

\section{Factors of enforcing innovations in services}

An intangible nature of services, requiring the customer's participation and a variable, inevitably leads to a continuous and consequential innovation focused on the customer satisfaction. Success of the innovation introduced in services depends from a clear understanding of customer needs (Chesbrough, and Spohrer, 2006). Enterprises that are able to identify customer needs and harmonise them with key competences are more profitable and innovative than those that cannot do that (Fuller and Matzler, 2007). Service innovation is a process that is highly demanding for each employee of a service enterprise.

Likewise technologies and of them especially information technologies play an important role in the service production. A fast boom of the Internet and a mobile links made marketing specialists focus on the speed, planning and electronic access, and in this way accelerate the process of producing or selling services. The customer wishes to obtain the service at any time, that is why the pressure exerted on the production of ICT (information and communication technologies) as the source of technology innovations in services is increasing. Online marketing, technologies for increasing the effectiveness enterprise activities, planning enterprise resources, managing relations with customers and with suppliers and others enable or facilitate service enterprises to innovate their processes, products, change corporate culture and enterprise's organisational structure. These technology innovations introduced largely in the past decade have significantly transformed the service sector.

In several studies there was explored a strategic role of information technologies (IT) in innovations (including innovation of services); these studies confirm that IT have considerably facilitated the innovation of services in numerous service industries (e.g. in health service, financial services, technical services, in management consultancy) (Kuo and Chao, 2014). Froehle and Roth (2004) list five ways of explaining the diversity of technology - mediated contacts with customers or the relationship with the customer in relation to technology. They include the entire spectrum of relationships between the provider and the client: ranging from the technology supporting the direct contact with the customer up to self-service technology.

Services are in general easy to imitate; protection against imitation has been little efficient to date. For this reason, for a service enterprise, a suitable way of acquiring a competitive advantage and asserting itself on the market is to introduce innovation in the process of 
service production, which differentiates it from its competitors and enables it to win the customer loyalty. That is why it is important to continuously innovate, so that the competitive advantage in a service enterprise might be not only achieved but also maintained. This concerns each party involved in the process of service production, customers, employees, and suppliers. Each of them plays an important role in the innovation of services. (Xiao and Ruoya, 2007).

A crucial moment in the production of services is involving the client in the process of providing services and developing relationships with the customer. Likewise, marketing and service delivery at the right time is an important moment appreciated by the customer. Creating rapport with the customer via the Internet and mobile networks is a fast growing trend, IT advancements enable the implementation of new technology innovations in services and support generating new ideas.

It is then no longer so decisive which type of innovation the service enterprise introduces. Raymond and St-Pierre (2010) confirm that even though the innovation of products and services is often examined separately as completely distinct, these two innovation types are mutually linked in the course of implementing the innovation process into the enterprise value chain (Fuller and Matzler, 2007).

\section{Method}

The paper deals with the relation between the innovation activity of service enterprises and the economic effectiveness expressed in terms of productivity of labour in services. It uses the method of correlation between the enterprise innovation activity and the productivity of services in the service sector. For this purpose, one research question and one hypothesis were formulated.

Research question: Is the scope of enterprise innovation activities a determinant of the productivity of labour?

Hypothesis: Innovation expenditures in enterprises with technology innovation in selected service divisions in Slovakia influence the productivity of labour in these enterprises.

The verification of these statements was conducted by means of the correlation analysis. Via this analysis, we assessed links between individual variables, which enabled to us to test the initial problems identified. We used Spearman's correlation coefficient, which expresses the rate of dependence of two variables $\mathrm{X}$ and $\mathrm{Y}$. It can assume the values -1 (negative correlation), +1 (affirmative correlation) and 0 (there exists no relationship between the variables).

The formula for Spearman's correlation coefficient is:

$$
\mathrm{r}_{s}=1-\frac{6 \sum \mathrm{d}_{\mathrm{i}}^{2}}{\mathrm{n}\left(\mathrm{n}^{2}-1\right.}
$$

where:

$\boldsymbol{d}_{\boldsymbol{i}}=$ difference between pairs of rank

$\sum \boldsymbol{d}_{i}^{2}$ sum of differences brought to a square

$\boldsymbol{n}=$ scope of set
The subject of exploration was the service sector in the SR. In the first part of results, we compared values of the productivity of labour achieved in services in the SR and average values achieved in EU countries in the year 2012. The given result is the starting-point for exploring the relation between innovation and productivity. In this comparison the productivity of labour is expressed in terms of gross added value per an employee. The given parameter is compiled from the most recent data of the Eurostat database (2016).

In the second, results part of the paper we used the publication of Slovak Statistics on the innovation activity of enterprises in the Slovak Republic (the Slovak Statistics, 2014) as a source. The document focuses on the research in industry and in selected divisions of services. The research was conducted in the year 2013 and concerned the referential period of 2010 - 2012; simultaneously, it is the most recent information base of relevant measurement. The effects of innovations expenditures on the productivity of labour was studied in the settings of exclusively technology innovators, namely for reasons of relevant data accessibility. As many as 4,122 reporting units were involved in investigation. The statistical unit was an enterprise. The data processed are provided in answers gained from 2,897 respondents. For the needs of our investigation, we used data for the following decisions of the service sector classified after SK NACE:

. 46 Wholesale trade except the repair of motor vehicles

.49 - 53 Transport and storage

. 58 - 63 Information and communication

$.64-66$ Financial and insurance services

. 71 Architectural and engineering activities, technical testing and analyses

. 72 Scientific research and development

.73 Advertising and market research

The research classifies enterprises in terms of scope and character of innovation activity. It defines enterprises with innovation activity as well as those without the innovation activity and the enterprises with completed technology innovation and non-technology innovation. Productivity of labour is expressed in the volume of sales on one employee.

The aim of the article is to identify the relation between the innovation activity of enterprises and the productivity of labour in services in the Slovak economy.

\section{Results and discussion}

We consider the comparison of values of productivity achieved in selected services in Slovakia's economy and average values achieved in EU-28 to be a starting argument in favour of next exploration into the causes of this condition. Graph 1 documents below the average selected parameter values in all the selected services in the SR, in comparison with the EU average. The most distinct difference may be observed in the field of Scientific research and development, further in the field of Architectural and engineering activities. Despite the fact that the highest value of the productivity of labour achieved in the SR is recorded in the Information and communication field, its difference from the average value for the $\mathrm{EU}$ is considerable. 
Figure 1. Gross value added per employee in services, comparison of the EU and the SR, 2012, in € thousand

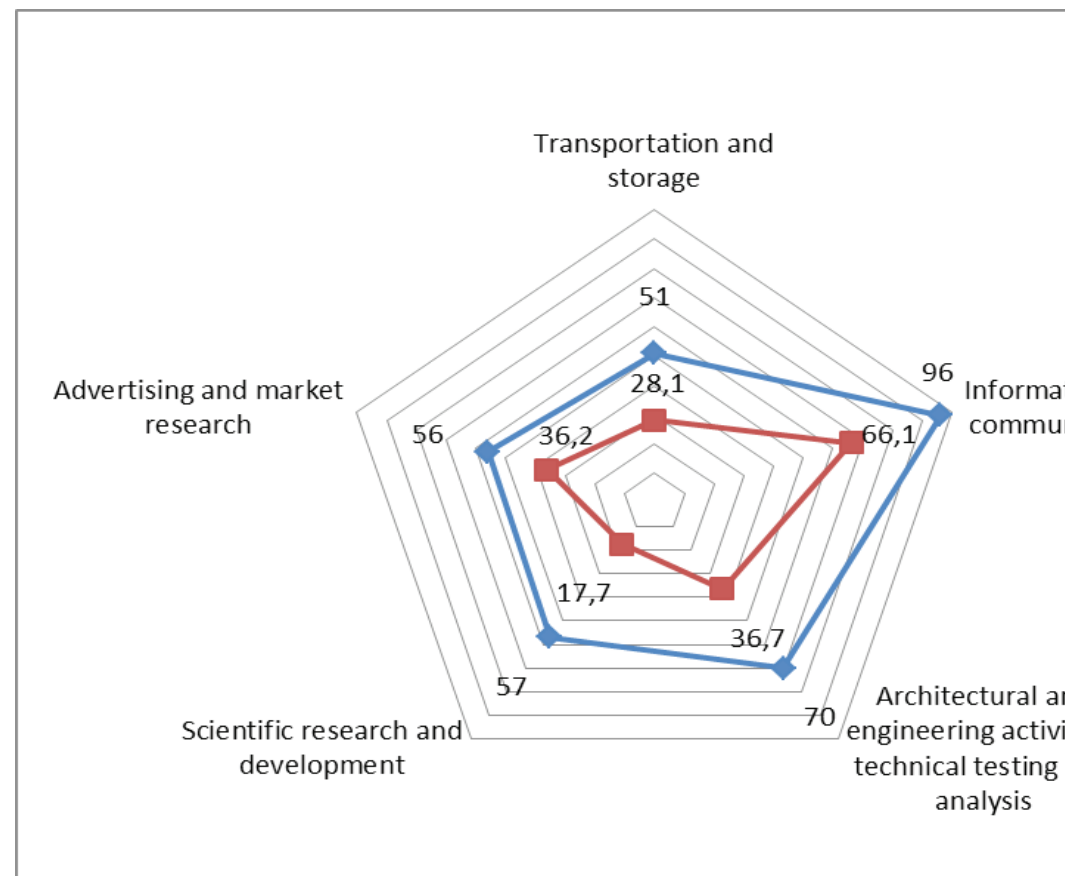

Own processing, data from Annual enterprise statistics for special aggregates of activities (NACE Rev. 2) . Eurostat (2016)

Verification of the research question: Is the scope of innovation activities of enterprises a determining factor of the productivity of labour in the service sector?

Table 1. Productivity of labour in individual divisions of Slovakia's services for the year 2012

\begin{tabular}{|c|c|c|c|}
\hline \multicolumn{4}{|c|}{ Enterprises involved in innovation activities } \\
\hline $49-53$ Transport and storage & 3064358 & 58873 & 52,05 \\
\hline $58-63$ Information and communication & 2514345 & 18812 & 133,66 \\
\hline $\begin{array}{c}71 \text { Architectural and engineering activities, technical } \\
\text { testing and analyses }\end{array}$ & 206805 & 2687 & 76,97 \\
\hline 72 Scientific research and development & 35081 & 614 & 57,14 \\
\hline 73 Advertising and market research & 295636 & 2058 & 143,65 \\
\hline & $\begin{array}{c}\text { Turnover } \\
\text { (in thousand } € \text { ) }\end{array}$ & Employees & $\begin{array}{r}\text { Productivity of labour } \\
\text { (thousand } € \text { /employee) }\end{array}$ \\
\hline 46 Wholesale trade except repair of motor vehicles & 12254930 & 35797 & 342,35 \\
\hline $49-53$ Transport and storage & 3142732 & 34549 & 90,96 \\
\hline 58 - 63 Information and communication & 2155924 & 13507 & 159,62 \\
\hline 64 - 66 Financial and insurance activities & 1848327 & 3862 & 478,60 \\
\hline
\end{tabular}




\begin{tabular}{|c|c|c|c|}
\hline $\begin{array}{l}71 \text { Architectural and engineering activities, technical } \\
\text { testing and analyses }\end{array}$ & 435620 & 5769 & 75,51 \\
\hline 72 Scientific research and development & 2673 & 129 & 20,72 \\
\hline Total services $46-73$ & 20095284 & 95554 & 210,30 \\
\hline \multicolumn{4}{|c|}{ All enterprises } \\
\hline 46 Wholesale trade except repair of motor vehicles & 21164131 & 61857 & 342,15 \\
\hline $49-53$ Transport and storage & 6207090 & 93422 & 66,44 \\
\hline $58-63$ Information and communication & 4670270 & 32319 & 144,50 \\
\hline 72 Scientific research and development & 37753 & 743 & 50,81 \\
\hline 73 Advertising and market research & 550714 & 3998 & 137,75 \\
\hline Total services $46-73$ & 40503390 & 231160 & 175,22 \\
\hline
\end{tabular}

Own processing. Data from the Slovak Statistics. Inovačná aktivita podnikov v Slovenskej republike 2010 - 2012 (2014)

\section{Spearman's test for correlation}

\begin{tabular}{|c|c|c|}
\hline Scope of set & $\mathrm{n}=7$ & $\mathrm{n}=7$ \\
\hline Sum of differences brought to a square & $\mathrm{d}_{\mathrm{i}}^{2}=4$ & $\mathrm{~d}_{\mathrm{i}}^{2}=4$ \\
\hline Level of significance & $a=0,01$ & $a=0,01$ \\
\hline
\end{tabular}

Acquired affirmative values point to the existence of a positive dependence between the total productivity achieved in the service industry and the productivity of labour achieved in innovative or non-innovative enterprises. To investigate statistical significance, we used the level of significance $a=0,01$. Since the scope of set of investigated magnitudes was smaller than 30 , we used testing statistics. For the level of significance $\mathrm{a}=0,01$ and $\mathrm{n}=7$, we acquire the critical value of $r_{0} r_{0}=0,8929$. Since $r_{s} r_{s}>r_{0} r_{0}$, we refuse the zero hypothesis. However, based on the correlation analysis results, it cannot be claimed that in the year 2012 the productivity of labour in selected service divisions influenced the innovative enterprises to a greater extent than the enterprises without innovation activity, since the values are the same.
When comparing the enterprises with innovation activities and those without innovation activity, we find that a higher

productivity of labour is generated in enterprises without innovation activity. However, in certain service divisions the productivity of labour is higher in enterprises with innovation activity. These are mainly knowledge-intensive services. The scope of innovation activity is therefore a determinant of the productivity of labour only under specific production conditions. This holds for the following service subsectors: architectural and engineering activities, technical testing and analyses; scientific research and development; advertising and market research. A knowledge-intensive nature of production in these service divisions influences the productivity of labour by means of applied innovations. Innovations are in this way a determinant of the productivity of labour mainly in the knowledge-intensive services. 
Reflections on the influence of innovations on the productivity of labour in services, however, run against the fact of heterogeneity of services. This is characteristic of differences in processes of service production in terms of a differing share of live and materialised labour. A high share of human work performance determines the effects from innovation implementation, in particular in product and organisational innovations. In fact, product creation and organisation are the areas the most influenced by human performance.

Verification of hypothesis No. 1: Expenditures on innovations in enterprises with technology innovation in selected service divisions in Slovakia influence the productivity of labour in these enterprises.

Table 2 Expenditures on innovations in enterprises with technology innovation in the year 2012 in selected service divisions in the SR (in thousand EUR)

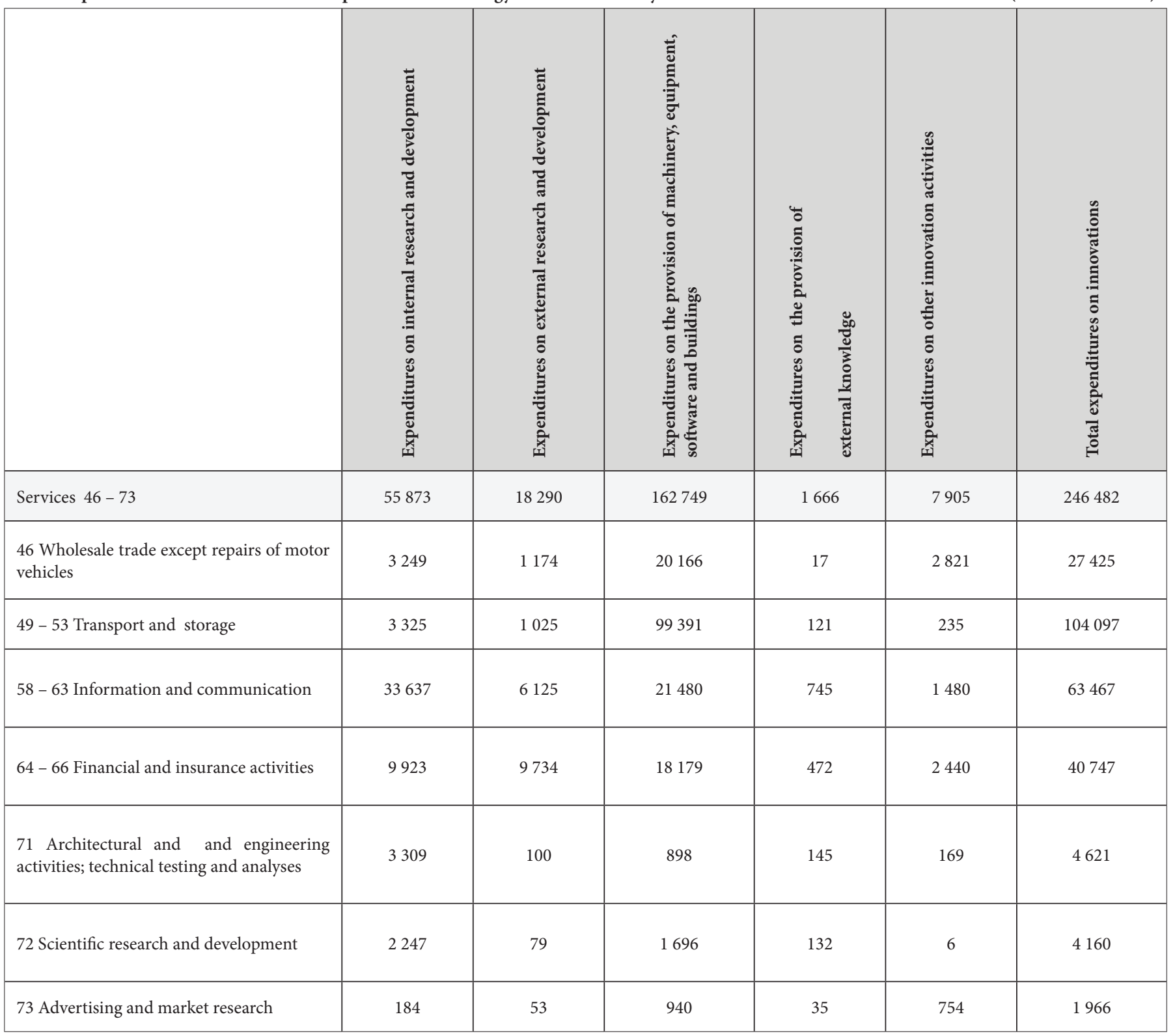

Own processing. Data from the Slovak Statistics. Inovačná aktivita podnikov v Slovenskej republike 2010 - 2012 (2014)

The highest expenditures on innovations in the Slovak Republic were spent in the year 2012 by large enterprises. In selected services their share of the total expenditures accounted for $64.5 \%$. The highest expenditures on innovations in selected services were into the following areas:
. Provision of machinery, equipment, software, and buildings (66.03\%);

- Internal research and development (22.67\%);

- External research and development (7.42\%);

- Expenditures on all other innovation activities (3.21\%);

- Provision of other external knowledge (0.67\%) (the Slovak Statistics, 2014). 
Table 3. Database for the calculation of the relation between innovation expenditures per employee in enterprises with technology innovation and the productivity of labour in these enterprises, selected service divisions, SR, 2012

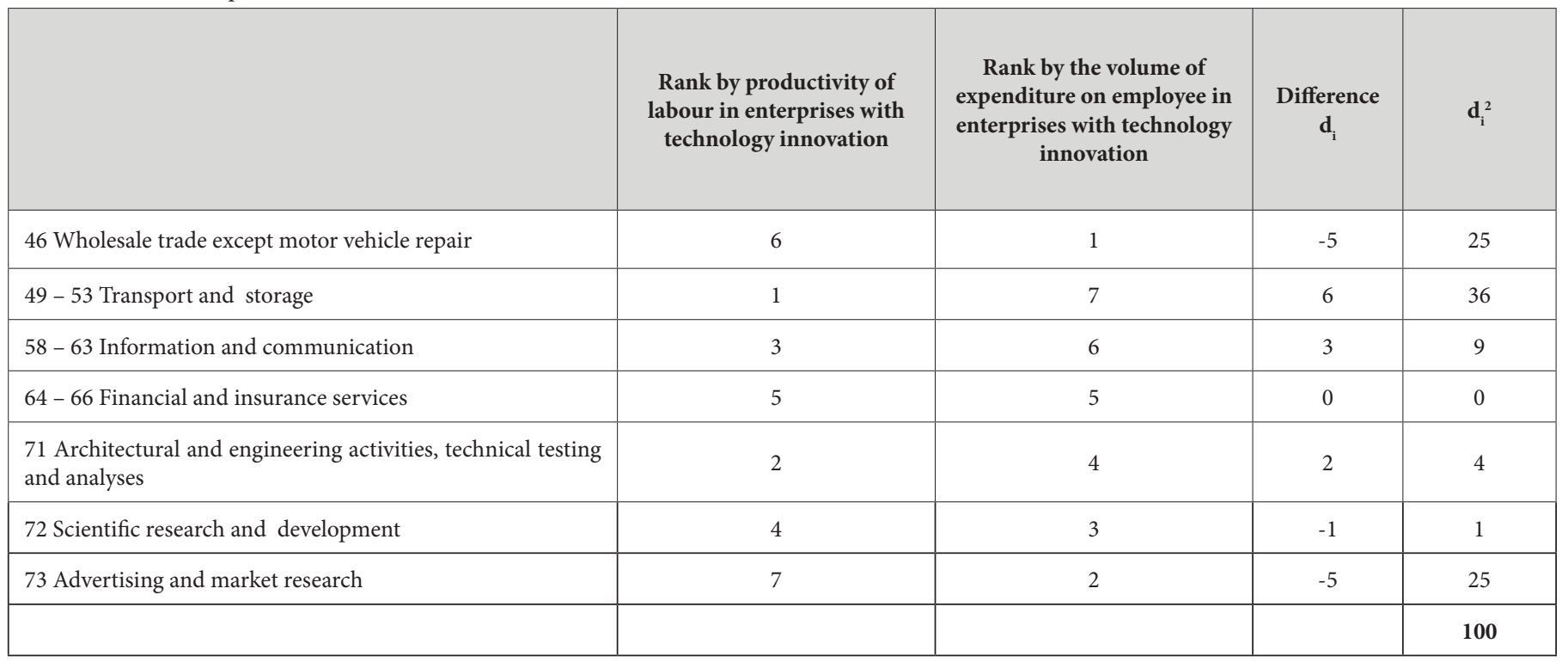

Own processing. Data from the Slovak Statistics. Inovačná aktivita podnikov v Slovenskej republike 2010 - 2012 (2014)

Scope of set

$\mathrm{n}=7$

Sum of differences brought to a square

$$
\mathrm{d}_{\mathrm{i}}^{2}=100
$$

Level of significance

$a=0,01$

\section{Spearman's test for correlation}

$$
r_{s}=1-\frac{6 \sum d_{i}^{2}}{n\left(n^{2}-1\right)}=1-\frac{6(100)}{7(48)}=-0,78
$$

This correlation analysis does not validate the dependence between the volume of expenditures on innovations per one employee and the productivity of labour in enterprises with the introduced technology innovation. The volume of expenditures on innovations is not in the direct positive relationship to the volume of the total of generated sales per an employee.

These findings, however, accept the time factor only partially. Time plays a key role in the rise of effects from implemented service innovations. Apart from the logical time interval between implementation and efficiency of innovations, there exists in services a phenomenon of consumption based on trust. This way the consumption reacts to innovation with the time-lag, which affects delayed economic effects expressed in terms of turnover.

\section{Conclusion}

Innovations are under conditions of competition a key instrument of sustainable development of the firm and the entire national economy. According to the theory, a leading role is ascribed to innovations in the processes of achieving competitiveness and economic performance of the firm. They are means of differentiating from the competition, cost cutting instruments, and those of satisfying customers. However, are they going to create space for increasing productivity under conditions of service production? The sector of market services has an important position in Slovakia's economy. Within comparison values with EU countries, however, Slovakia is lagging behind the average values in the areas of performances as well as innovation activity. The correlation analysis described in the paper demonstrates a positive relation between the productivity of labour in individual service subsectors and the total productivity of labour achieved in Slovakia's economy. However, there is no difference between the influence of productivity of labour in innovative service enterprises and in non-innovative service enterprises to a parameter of the total productivity of labour. Knowledge-intensive services, however, achieve a higher productivity of labour, as long as innovate. Thereby, innovations are determinants of the productivity of labour in knowledge-intensive services; however, they are not decisive parameters for achieving the productivity of labour in the service sector in total.

Another relation explored was the relation of volume of expenditure on innovations on the productivity of labour in service sectors with introduced technology innovation. The correlation analysis applied did not corroborate the dependence between the volume of expenditures on innovations and productivity of labour in enterprises with introduced technology innovation. The volume of expenditure on innovations is not in direct positive relation to the volume of generated total sales per an employee.

For a deeper understanding of the phenomena explored, in the next research it will be relevant to incorporate the time factor in the study by means of correlation and regression analyses. Time plays a crucial role in efficiency indicators of implementing innovations in the service sector. 


\section{Acknowledgement}

Problems described in the present paper constitute part of the research project under the nation-wide research grant agency VEGA, project No.1/0205/14 "Perspectives of existence of dynamic service enterprises in the Slovak Republic in the context of applying the principles of the initiative "Innovations in the Union"'.

\section{References}

Balci, B., Hollmann, A. \& Rosenkranz, C. (2011). Service Productivity: A Literature Review and Research Agenda. XXI. International RESER Conference. Hamburg.

Baumgärtner, M. \&Bienzeisler, B (2006). Dienstleistungsproduktivität. Konzeptionelle Grundlagen am Beispiel interaktiver Dienstleistungen. Stuttgart: Fraunhofer-IRB-Verl.

Brown, R., Mawson, S. (2013). Triggerpoints and high-growth firms: A conceptualisation and review of public policy implication. Journal of Small Business and Enterprise Development, 20(2), 297-295.

Brown, F. \& Chávez, G.A.G. (2014). Innovation and Productivity Across Mexican Manufacturing Firms. Journal of Technology Management \& Innovation, 9(4), 36-52.

Corsten, H. (2001). Dienstleistungsmanagement. 4. Aufl., München, Wien.

Corsten, H. (1994). Produktivitäts management bilateraler personen-bezogener Dienstleistungen. In H. Corsten \& W. Hilke (Hg.), Dienstleistungsproduktion (pp.43-77). Wiesbaden: Th. Gabler.

Den Hartigh, E. \& Zegveld, M. (2011). Service Productivity How to Measure and Improve It? Service Systems Implementation, Service Science: Research and Innovations in the Service Economy, eds. H. Demirkan et. al., 183- 198.

European Commision. (2015). ESIS 2015 Retrieved from http:// ec.europa.eu/growth/tools-databases/esic/scoreboard/index_en.htm

European Commision, (2015). Innovation Union Scoreboard Retrieved from http://ec.europa.eu/enterprise/policies/innovation/policy/ innovation-scoreboard/index_en.htm

Eurostat. (2016). Annual enterprise statistics for special aggregates of activities Retrieved from http://appsso.eurostat.ec.europa.eu/nui/ show.do

Froehle, C. M. \& Roth, A. V. (2004). New measurement scales for evaluating perceptions of the technology-mediated customer service experience. Journal of Operations Management, 22 (1), 1-21.

Fuller, J. \& Matzler, K. (2007). Virtual product experience and customer participation - A chance for customer-centred, really new products. Technovation, 27(6), 378-387.
Grönroos, C. \& Ojasalo, K. (2004). Service productivity.Towards a conceptualization of the transformation of inputs into economic results in services. Journal of Business Research, 57(4), 414-423.

Gummesson, E. (1998). Productivity, quality and relationship marketing in service operations. International Journal of Contemporary Hospitality Management, 10( 1), 4-15.

Hilke, W. (1989). Grundprobleme und Entwicklungstendenzen des Dienstleistungs- Marketing. In H. Jacobet at.al. (ed.), Dienstleistungs-Marketing: Banken und Versicherungen - Freie Berufe - Handel und Transport (pp.5-44). Wiesbaden: Th. Gabler.

Chesbrough, H. \& Spohrer, J. (2006). A research manifesto for service science. Communications of the ACM, 49(7), 35-40.

Jääskeläinen, A. (2010). Identifying factors affecting public service productivity. International Journal of ServicesTechnology and Management, 14(4), 360-375.

Johnston, R. \& Jones, P. (2004). Service Productivity. Towards understanding the relationship between operational und customer productivity. International Journal of Productivity and Performance Management, 53(3), 201-213.

Kuo, D. C. L. and Chao, Ch.Y., 2014, "Exploring the relationships amongst patterns, information technology, and performance in SMEbased service innovation", International Journal of Electronic Business Management, 12(2), 102-111.

Lasshof, B. (2006). Produktivität von Dienstleistungen.Mitwirkung und Einfluss des Kunden. Fernuniversität Hagen, Wiesbaden.

Maleri, R. \& Frietzsche, U. (2008). Grundlagen der Dienstleistungsproduktion. Berlin, Heidelberg.

Mansury, M. A. \& Love, J. H. ( 2008). Innovation, productivity and growth in US business services: A firm-levelanalysis. Technovation, 28 (1-2), 52-62.

Michalová, V. \& Krošláková, M. (2014) Obchodno-podnikatel'ské služby. Bratislava: Vydavatelstvo Ekonóm.

Ojasalo, K. (1999). Conceptualizing productivity in services. Helsingfors: Swedish School of Economics and Business Administration.

Raymond, L. \& St-Pierre, J. (2010). R\&D as a determinant of innovation in manufacturing SMEs: Anattemptatempiricalclarification. Technovation, 30(1), 48-56.

Rhee, J., Park, T. \& Lee, D. H. ( 2010). Drivers of Innovativeness and Performance for Innovative SMEs in SouthKorea: Mediation of Learning Orientation. Technovation, 30(1), 65-75.

Sedláček, M. (2014). Význam inovácií v regionálnom rozvoji. Sociálno-ekonomická revue, 12(1), 79-96. 
Sink, D. S. (1985). Productivity management. Planning, measurement and evaluation, control and improvement. New York; Toronto: J. Wiley.

The Slovak Statistics (2014). Inovačná aktivita podnikov v Slovenskej republike 2010 - 2012. Bratislava : ŠÚSR, 250.

The Slovak Statistics (2015). Retrieved from http://statdat.statistics.sk/cognosext/cgi-bin/cognos.cgi?b_action=cognosViewer\&ui. action $=$ run\&ui.object $=$ store $I D(\% 22 \mathrm{i} 6 \mathrm{~B} 65329 \mathrm{BEA} 5 \mathrm{~A} 4855 \mathrm{AD}$ 33D389E199D10A\%22) \&ui.name=Ekonomick\%c3\%a9\%20 ukazovatele \%20za\%20vybran\%c3\%a9\%20 trhov\%c3\%a9\%20 slu\%c5\%beby\%20pod\%c4\%bea\%20SK\%20NACE\%20Rev.\%202\%20 $\% 5 \mathrm{bts} 1001 \mathrm{rs} \% 5 \mathrm{~d} \&$ run.outputFormat=\&run.prompt=true\&cv.header=false\&ui.backURL=\%2fcognosext $\% 2$ fcps $4 \% 2$ fportlets $\% 2$ fcommon\%2fclose.html
Vuorinen, I., Järvinen, R. \& Lehtinen, U. (1998). Content and measurement of productivity in the service sector: A conceptual analysis with an illustrative case from the insurance business. International Journal of Service Industry Management, 9(4), 377-396.

World Economic Forum. (2016). Retrieved from http://reports.weforum.org/global-competitiveness-report-2015-2016/competitiveness-rankings/

Xiao, H. CH. \& Ruoya, L.U. (2007). Study on Service Innovation with Employee and Costumer Involvement-based on Service Profit Chain Retrieved from http://www.seiofbluemountain.com/upload/product/200911/2007qyczhy5z4a3.pdf, 